\title{
Inoculation of Pinus halepensis with the Ectomycorrhizal Fungi Scleroderma Helps in Phytoremediation of Soil Polymetallic Pollution
}

\author{
Elmehdi Ouatiki ${ }^{1,2,5}$, Abdessamad Tounsi ${ }^{1,2}$, Soumia Amir ${ }^{1}$, \\ Laila Midhat ${ }^{3,4}$, Mohamed Radi ${ }^{5}$, Lahcen Ouahmane ${ }^{5 *}$
}

\begin{abstract}
${ }^{1}$ Polyvalent Laboratory in Research and Development, Beni Mellal Polydisciplinary Faculty, Morocco ${ }^{2}$ Research Team in Applied Chemistry and Modeling ERCAM, Faculty Polydisciplinary Beni Mellal, Morocco ${ }^{3}$ Laboratory of Hydrobiology, Ecotoxicology and Sanitation LHEA (URAC33), Faculty of Sciences Semlalia, Cadi Ayyad University, Marrakesh, Morocco

${ }^{4}$ National Center for Research and Studies on Water and Energy (CNEREE), BP/511, University Cadi Ayyad, Marrakesh 40 000, Morocco

${ }^{5}$ Laboratory of Microbial Biotechnologies, Agro-sciences and Environment (BioMAgE), Faculty of Sciences Semlalia, Cadi Ayyad University, Marrakesh, Morocco
\end{abstract}

Received: 7 September 2020

Accepted: 27 December 2020

\begin{abstract}
This study aims to evaluate the effectiveness of Pinus halepensis inoculated with the ectomycorrhizal fungi spores belonging to Scleroderma in phytoremediation of polymetallic soil. Tailings were collected in the Kettara polymetallic abandoned mine in southern Morocco and diluted with sand in the following proportions, $10 \%, 25 \%, 50 \%$ and $75 \%$. The pots experiment was conducted for six months under greenhouse conditions. The results show that the studied plant reveals a great tolerance even at high proportion of contaminated soil (75\%). The average length and biomass of the aerial and root parts of both inoculated and non-inoculated seedlings decreased with the increase of the proportion of the polluted soil. The inoculated seedlings have shown higher length and biomass than non-inoculated seedlings. The symbiotic association between Pinus halepensis and the fungus Scleroderma could be proposed as an ultimate solution for the phytoremediation of polluted soils.
\end{abstract}

Keywords: Pinus halepensis, Phytoremediation, heavy metals, ectomycorrhizae, Scleroderma

*e-mail:1.ouahmane@uca.ac.ma 


\section{Introduction}

The evolution of culture, science and demographic explosion increase the overexploitation of natural resources to satisfy human needs. Natural and intensive anthropogenic activities are the main factors disturbing the natural environment of the Earth and the equilibrium of terrestrial ecosystem [1]. Mining activities are a major anthropogenic source of releases of metals into the environment. These exploitations generate beneficial and harmful wastes, which were deposited on surface without any treatment [2]. At first, the effects of these wastes were negligible because of their small quantity, but progressively they become enormous and widely dispersed throughout the environment and present serious risks to human health and environmental issues.

Morocco has an important mining activity and is therefore known for its many active and abandoned mining sites in particular for those quarrying $\mathrm{Cu}, \mathrm{Zn}$, $\mathrm{Pb}$ and $\mathrm{Fe}$. Among the abandoned mines the Kettara site located in the northwest of Marrakesh with about 30 ha of polymetallic discharges containing more than three million tons of sulfurous mine discharges [3-5] [6]. Recently, Moroccan mining legislation requires that the exploitation is carried out with rational methods and regulations based on health, safety and environmental protection $[7,8]$.

Phytoremediation has been highlighted as a potentially reliable and cost-effective alternative to conventional techniques for the remediation of polymetallic soils [9]. It basically refers to the use of plants and associated soil microbes to reduce the concentrations or toxic effects of contaminants in the environment [10]. Plants can naturally reduce mobility and bioavailability of the heavy metals in soil as they are absorbed in roots or/and aerial parts [11]. This natural remediation process can be accelerated by the addition of microorganisms [12], which has the ability of reducing the biological availability of metals and enhancing their uptake in plant biomass. This natural symbiosis between those two partners allows a connection in which the plant supplies photosynthetic products or metabolites to the fungus and this former offers water and mineral elements to the plant from the surrounding soils [13]. Pinus halepensis, a coniferous plant species, is used for phytoremediation in our study. It grows mainly in the thermo and meso-Mediterranean bioclimates [14] and covers about 3.5 million hectares of [15]. The tree is adapted to growth on marly and calcareous marly limestone, schists and micaschists [16]. This conifer can live up to 150 years with an important biomass and a length of $25 \mathrm{~m}$ [17]. Its leaves in the form of needles of 6-12 cm, the cones of ovoid conical shape of 8 to $12 \mathrm{~cm}$ long [18] carrying consumable seeds.

About $90 \%$ of vascular plants have the ability to create a symbiotic relationship with living organism especially fungi [19]. One kind of resulting structure formed between plant roots and fungi is called a mycorrhiza [19]. The fungus scleroderma is a basidiomycete

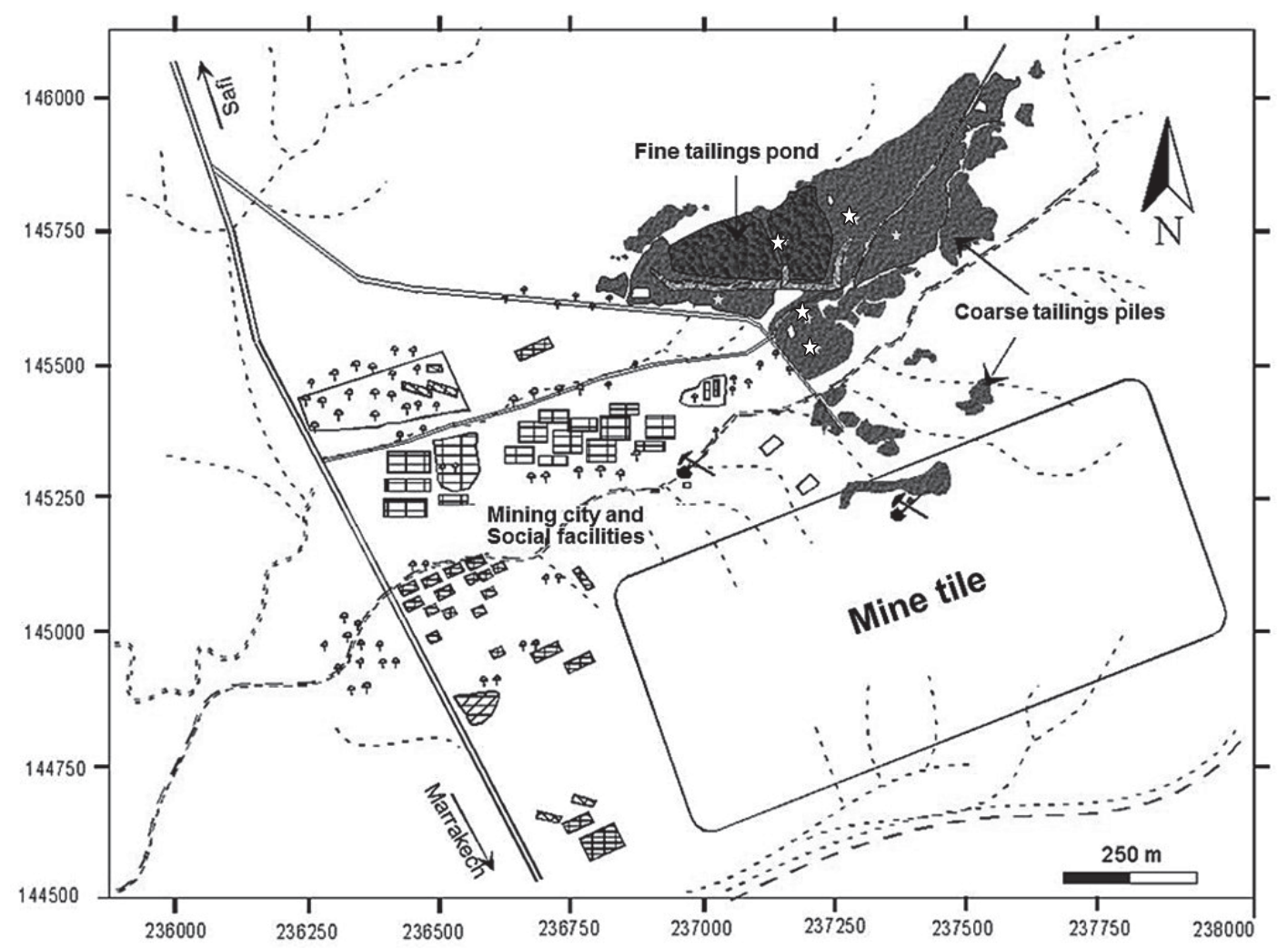

Fig. 1. Location of tailing samples collected from Kettara mine site (§) soil Sampling Points [58]. 
belonging to the Sclerodermataceae family whose name comes from the Greek Skleros "hard" and Derma "skin". Thirty species were identified, often in fairly humid places, they are associated with different families of host plants of great importance: Pinaceae, Myrtaceae, Fagaceae [20]. Many researchers confirmed that this symbiotic relationship improves the supply of water and nutrients for plants, enhances their resistance to stressful conditions $[21,22]$ and reduces the available heavy metals in the soil, thereby decreasing their toxicity to host plants [23].

The main objective of this research was to evaluate the effectiveness of the symbiotic relationship between Pinus halepensis and Scleroderma for further phytoremediation of polymetallic soils.

\section{Material and Methods}

\section{Site Description}

The contaminated soil selected for the current study is originated from the tailings of abandoned Kettara mine, located approximately at $35 \mathrm{~km}$ northwest of Marrakesh, in the center of the central Jebilet Mountains (Fig. 1).

\section{Soil Sampling and Analysis}

The climate of the area is semi-arid with annual average rainfall of approximately $250 \mathrm{~mm}$ and the evapotranspiration can reach $1500 \mathrm{~mm} /$ year [24]. The mine was active for many years for the extraction of copper, zinc, iron, and cadmium, and its environmental characteristics have been previously described by several authors $[3,25,26]$. The abandoned Kettara mine site is almost 30 hectares of toxic mining waste containing more than three million tons of sulphurous mining wastes [26] exposed to rain, sun and wind [5]. Therefore, they create major environmental problems that affect the health of living beings. Soils sampling were collected randomly from tailings in the field of the study. Samples were taken after the removal of $2 \mathrm{~cm}$ of superficial layer [27] to collect about 3-4 kg of polluted soil mass from each sampling point. Samples were stored in polyethylene bags to prevent the escape of soil powder [27]. In the laboratory, the samples were mixed in order to obtain an almost homogeneous substrate suitable for further physico-chemical analysis and adequate for use as a culture substrate. Physical and chemical soil properties were determined as reported by the standard procedures published in the Official Methods of Soil Analysis [28]. The $\mathrm{pH}$ and Electrical conductivity (EC) were determined in water suspension ( $1 \mathrm{v}: 2 \mathrm{v}$, soil: distilled water), and (1v:5v soil: distilled water), respectively. The measurements were carried out using a multi-parameter probe type LF 92 WTW. The texture was determined using the Robinson pipette method joined with sieving. Calcium carbonates equivalent was determined using Bernard calcimeter. The total organic carbon (TOC) was determined by Anne method [28]. The total Kjeldahl nitrogen (TKN) was determined using the Kjeldahl method [29]. Major elements [Calcium (Ca), Sulfur (S), phosphorus (P) and Iron $(\mathrm{Fe})$ ] and trace elements [Zinc $(\mathrm{Zn})$, Copper $(\mathrm{Cu})$, Lead $(\mathrm{Pb})$ and Cadmium $(\mathrm{Cd})$ ] were determined by $\mathrm{X}$-ray fluorescence spectrometry (OLYMPUS).

\section{Sampling of the Fungus}

In the beginning of April, the fruiting bodies of the fungus Scleroderma were collected from the Guedmioua forest located at about $60 \mathrm{~km}$ south-west of the city of Marrakesh. In this forest the main plant cover is formed by green oak, juniper and Pinus halepensis [30]. The symbiotic relationship studied was between Pinus halepensis as a host plant and Scleroderma sp. as mycorrhizal fungus. They were selected at wetlands of the forest and under the trees of the Pinus halepensis $[22,31]$. Harvested fruiting bodies were immediately stored in wax paper bags and transported to the laboratory [32], aiming the preparation of a fungal inoculum to be used with Pinus halepensis seedlings.

\section{Seeds Germination}

Pinus halepensis seeds were collected from the nursery of the Provincial Directorate of Water and Forest of Marrakesh. Seeds were pretreated to reduce the dormancy period by creating suitable conditions reproducing those of wild nature [33]. In order to ensure a total germination of the used seeds, stratification method was conducted in the slightly dampened sand for 14 days at $25^{\circ} \mathrm{C}$ [33]. The seeds were put to germinate, in sterile Petri dishes containing a filter paper with 20 seeds per dish. The dishes were daily soaked with $5 \mathrm{ml}$ of distilled water, seeds were germinated when they showed a radicle of $1 \mathrm{~mm}$ [33].

\section{Culture Substrate}

The cultivation substrate is composed of Kettara mine soil mixed or not with sand. Before using the soil of the studied mine, large particles that may interfere with the evolution of the roots of the seedlings during the experiment were removed and then disinfected in a Pasteur oven $\left(120^{\circ} \mathrm{C} / 40 \mathrm{~min}\right)$ to eliminate the native microflora in the mine [34]. The sand used comes from a sand dune from Safi region. Before use, the sand has undergone several preparatory operations, starting with sieving to remove all debris such as stones, plants and animals. After, it was washed with water in order to eliminate the high salinity level, in the goal to not disturb the development of the seedlings [35], then the sand was left in the fresh air to dry. The preparation of the cultivation substrate was carried out by diluting the polluted soil with sand and creating a series of $0 \%-$ $10 \%-25 \%-50 \%-75 \%-100 \%$ of mine tailing. 


\section{Planting and Experimental Design}

The germinated seeds were planted in 5 litres pots (10 seeds/pot). Two groups of pots were prepared, one mycorrhized (M) (inoculated with the Mycorrhizal fungal spores) and the other non- mycorrhized (NM) (not inoculated). The seedlings were grown under $16 / 8 \mathrm{~h}$ light/dark photoperiod at $25 \pm 2^{\circ} \mathrm{C}$ day and $18 \pm 2^{\circ} \mathrm{C}$ night and $65 \%$ relative air humidity [36]. The seedlings were watered daily with distilled water to permanently maintain the culture medium humid in order to ensure the evolution of the plants and the fungus.

\section{Preparation of the Inoculum and Seedlings Inoculation}

Fresh fructifications of the Scleroderma fungus harvested from the Guedmioua forest have been lightly cleaned to remove foreign mycelia, other root and soil particles, which can cause microbial contamination. After open air drying, these fructifications were ground using a grinder with sterile distilled water until a homogeneous solution containing the suspended spores was obtained [36]. This suspension was stored at $4^{\circ} \mathrm{C}$ until use [37]. The inoculation was carried out by injecting the obtained suspension through holes in contact with the roots [38].

\section{Seedlings Harvest and Treatments}

After six months of culture, mycorrhizal and nonmycorrhizal seedlings were thoroughly removed to preserve mycorrhizal apexes. Afterwards, plants were regularly watered with distillated water to remove particles attached to the roots [27].

\section{Biomass Measurements}

Plants were separated into aerial parts (Ap) and roots $(\mathrm{R})$. In the fresh state, we measured the length of the root, the aerial part and their fresh mass of each seedling. Both parts of the seedlings were oven dried $\left(70^{\circ} \mathrm{C} / 48 \mathrm{~h}\right)$ [27] to measure their dry mass.

\section{The Ectomycorrhizal Colonization}

The Mycorrhizal roots $(1 \mathrm{~cm})$ of each treatment were observed under the stereo-microscope to account the number of short roots. The percentage of ectomycorrhizal colonization (\% EMC) was calculated according to the following formula $[39,40]$.

$\% \mathrm{EMC}=\frac{\text { Number of ectomycorrhizal short roots }}{\text { Total number of short roots }} \times 100$

\section{Statistical Analysis}

Statistical analysis of the growth parameter of plants was based on ANOVA test. The Student- Newman-
Keuls grouping test, the calculated means and standard deviations were so reported. The statistical significance was declared when $p \leq 0.05$. All the statistical analyses were performed using the IBM SPSS statistics 25 .

\section{Results and Discussion}

\section{Soil Characterization}

Pedological analyses of the tailings samples from Ketarra site were performed for fractions of dimensions $<2 \mathrm{~mm}$. The granulometry of the studied tailings was dominated by the fine-sand fraction (Table 1), reaching $55 \%$ indicating that our study site is characterized by a sandy texture. The results obtained for $\mathrm{pH}$ of the tailings $(2.22 \pm 0.11)$ allows us to presume that the Kettara mine site is characterized by an acidic $\mathrm{pH}$. The conductivity (EC) is of $1410 \mu \mathrm{s} \mathrm{cm}^{-1}$ which indicates a high salt content. The total Kjeldahl nitrogen (TKN) was low $(0.09 \%)$. However, the total organic carbon was relatively high $1.62 \%$. Whereas the results of the total contents of the major elements $\left(\mathrm{Ca}: 3.32 \mathrm{~g} \mathrm{~kg}^{-1}\right.$, S: $65 \mathrm{~g} \mathrm{~kg}^{-1}$ and P: $1.437 \mathrm{~g} \mathrm{~kg}^{-1}$ ) indicated that the tailings of Kettara mine were poor in calcium and phosphorus but rich in sulfur. The high level of sulfur is from pyrites $\left(\mathrm{FeS}_{2}\right)$ and pyrrhotite $(\mathrm{FeS})$ joining other metal sulphides. The concentrations of trace metals found in the Kettara tailings were $\left(\mathrm{Cu}: 2396 \mathrm{mg} \mathrm{kg}^{-1}\right.$ Zn $655 \mathrm{mg} \mathrm{kg}^{-1}$; $\mathrm{Pb}$ : $523 \mathrm{mg} \mathrm{kg}^{-1}$ and $\mathrm{Cd}: 65 \mathrm{mg} \mathrm{kg}^{-1}$. The comparison of these contents with the permissible concentrations of trace elements (Cu: $140 \mathrm{mg} \mathrm{kg}^{-1}, \mathrm{Zn}$ \& $\mathrm{Pb}: 300 \mathrm{mg} \mathrm{kg}^{-1}$ and $\mathrm{Cd}: 3 \mathrm{mg} \mathrm{kg}^{-1}$ ) in agricultural soils, indicates that the site of the mine Kettara could be considered as highly contaminated [41]. Based on these results, the low $\mathrm{pH}$ values were probably due to the sulfide [6]. The weak values of TKN lead to high $\mathrm{C} / \mathrm{N}$ ratio, which could disturb soil microbial activity $[13,42,43]$. Moreover, $\mathrm{C} / \mathrm{N}$ ratio is considered as one of the most important factors due to ist direct link with the nutrients required for microbial activities [44]. The acidic $\mathrm{pH}$ and the poor fertility can be considered as strong limiting factors for plant growth [13, 45]. In fact, $\mathrm{pH}$ is an important indicator of the soil quality and distribution of microbial community [46] concluded that.

\section{Effect of Mycorrhization on Pinus halepensis Seedlings Growth}

According to the obtained results, it is obvious that after six months of culturing, the Pinus halepensis seedlings inoculated with the ectomycorrhizal fungi in polluted soil had shown that, the morphological structure of the seedlings varied with the proportion of polluted soil and with the fungal spores inoculation. As expected, seedlings growth was inhibited in the substrate formed with $100 \%$ polluted soil due to the high acidity and to the extreme polymetallic pollution. 
Table 1. Characteristics of mean tailings collected from Kettara mine site.

\begin{tabular}{|c|c|c|}
\hline Parameter & Unit & Means \\
\hline $\mathrm{pH}\left(\mathrm{H}_{2} \mathrm{O}\right)$ & - & $2.22 \pm 0.11$ \\
\hline Electrical conductivity & $\mu \mathrm{S} \mathrm{cm}^{-1}$ & $1410.00 \pm 26.15$ \\
\hline Calcium carbonate $\left(\mathrm{CaCO}_{3}\right)$ & $\mathrm{mg} \mathrm{g}^{-1}$ & $5.74 \pm 1.05$ \\
\hline Total organic carbon (TOC) & $\%$ & $1.62 \pm 0.42$ \\
\hline Organic matter & $\%$ & $2.802 \pm 0.850$ \\
\hline Total Kjeldahl nitrogen (TKN) & $\%$ & $0.09 \pm 0.01$ \\
\hline Available phosphorus & $\mathrm{mg} \mathrm{kg}^{-1}$ & $1437.00 \pm 52.04$ \\
\hline Total $\mathrm{Cu}$ & $\mathrm{mg} \mathrm{kg}^{-1}$ & $2396.00 \pm 31.93$ \\
\hline Total Zn & $\mathrm{mg} \mathrm{kg}^{-1}$ & $655.00 \pm 1.38$ \\
\hline Total $\mathrm{Pb}$ & $\mathrm{mg} \mathrm{kg}^{-1}$ & $523.00 \pm 2.12$ \\
\hline Total Cd & $\mathrm{mg} \mathrm{kg}^{-1}$ & $65.00 \pm 4.82$ \\
\hline $\mathrm{Ca}$ & $\mathrm{g} \mathrm{kg}^{-1}$ & $3.32 \pm 0.34$ \\
\hline $\mathrm{S}$ & $\mathrm{g} \mathrm{kg}^{-1}$ & $65.00 \pm 2.16$ \\
\hline $\mathrm{Fe}$ & $\%$ & $13.12 \pm 0.08$ \\
\hline Coarse sand & $\%$ & $17.00 \pm 2.00$ \\
\hline Fine sand & $\%$ & $55.00 \pm 1.00$ \\
\hline Silt & $\%$ & $22.00 \pm 1.00$ \\
\hline Clay & $\%$ & $6.00 \pm 1.00$ \\
\hline
\end{tabular}

All the data were presented as the mean values \pm standard deviation, $\mathrm{n}=3$.

The average length of the Aerial parts (Fig. 2) and roots (Fig. 3) of mycorrhizal seedlings were significatively $(p<0.05)$ greater than those of non-mychorrizal seedlings in the different treatments. The mean percentage growth of the Aerial parts and roots were (24\%; 7\%), (54\%; 13\%), (36\%; 77\%), $(23 \% ; 64 \%)$ and $(28 \% ; 39 \%)$ in the treatments $0 \%, 10 \%, 25 \%, 50 \%$ and $75 \%$, respectively (Figs 2,3 ). The average dry biomass of the two parts of the seedlings (Figs 4-5), follows the same pattern as the length. The mean percentage of the dry biomass of the Aerial parts and roots were $(72 \%$; $33 \%),(40 \%$; $33 \%)$; (50\%; $84 \%),(28 \%$; $107 \%)$ and $(75 \%$; $81 \%$ ) in the different treatments $0 \%, 10 \%, 25 \%, 50 \%$ and $75 \%$, respectively.

The average length, the biomass of the Aerial parts and roots in mycorrhizal seedlings are higher in all the soil dilutions than in non-mycorrhizal seedlings. These results, confirm the beneficial effect of mycorrhizal inoculation on reducing the impact of soil pollution and on increasing the ability of the studied plant to tolerate a high pollution rate which can reach $75 \%$.

Numerous studies had reported the beneficial effects of inoculation with various ectomycorrhizal fungi on the growth of host plants, such as Pinus halepensis with a sporal suspension of Suillus collinitus [47]. The inoculation of Pinus sylvestris with the ECM fungi showed greater tolerance to heavy metal, enhanced survival rates, increased nutrient absorption and growth of plants. At the same time, the ECM fungi could survive in heavy metal tailings ponds [23]. Other researchers approved that after one month of planting, Pinus densiflora inoculated with Pisolithus sp. on $\mathrm{Cu}$ tailings, had shown a survival rate higher than $50 \%$ compared to non-mycorrhizal plants with only $16.7 \%$ [48]. Other authors, such as [49], had found that the number of shoots, the total dry biomass and chlorophyll content of mycorrhizal plants were higher than those of non-mycorrhizal plants after a water stress. As well as, in the previous study, it was concluded that mycorrhizae stimulated growth, mineral nutrition and biochemical element contents in date palm plants at the eight study sites undergoing the same water stress conditions [50]. The beneficial effect of the use of mycorrhizae in case of metallic stress has been demonstrated by other authors, which showed that the use of arbuscular mycorrhizal fungi (AMF) increased plant length and biomass for all the treatments compared to their counterparts not inoculated by AMF [51]. Indeed, it could be concluded that ectomycorrhizal fungi act by promoting absorption and improving the nutritional status of the plant and promotes its growth, by decreasing heavy metal concentrations, thereby reducing the toxic effects of heavy metals on host plants, as suggested in other studies [52]. 


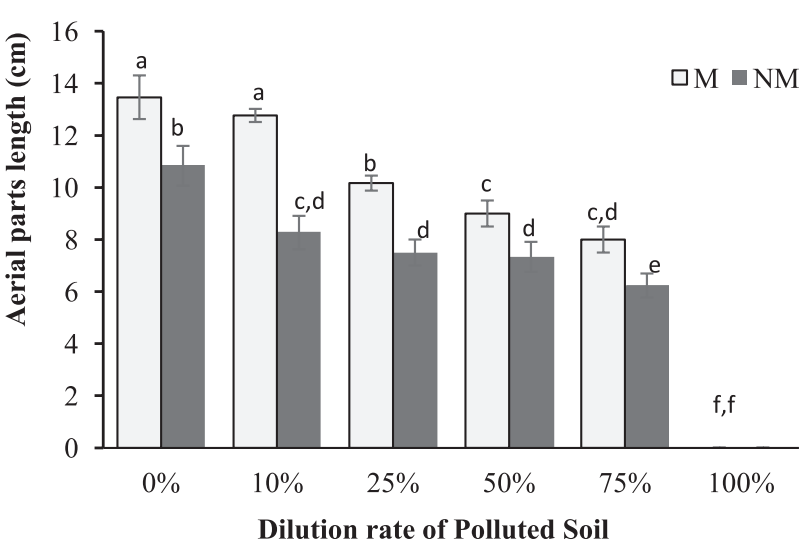

Fig. 2. Aerial parts length of mycorrhizal (M) and nonmycorrhizal (NM) seedlings in terms of the dilution rate of the polluted soil.

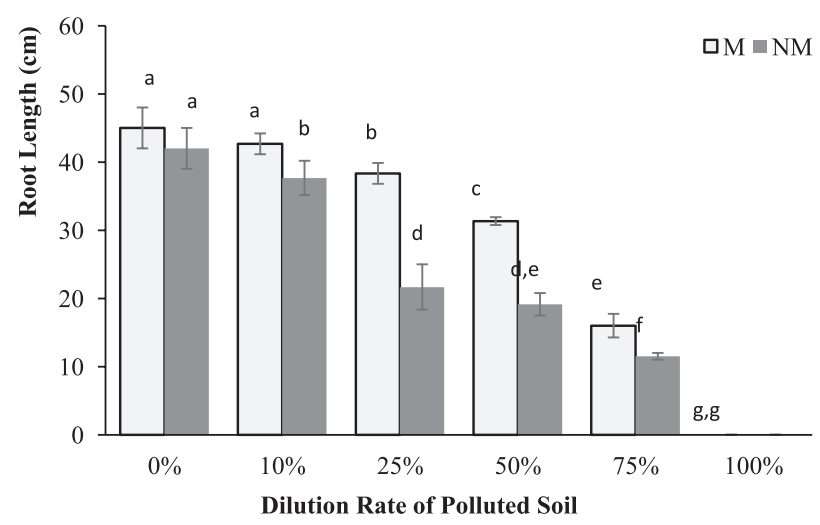

Fig. 3. Root length of mycorrhizal (M) and non-mycorrhizal (NM) seedlings in terms of the dilution rate of polluted soil.

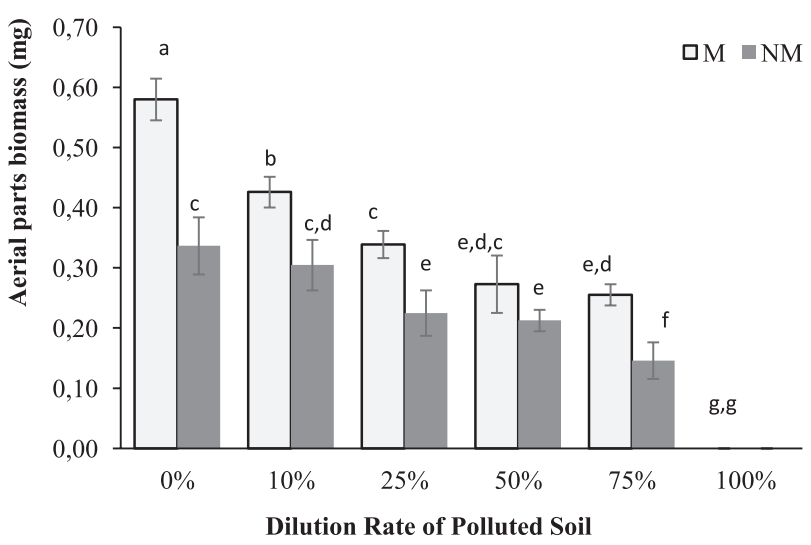

Fig. 4. The biomass of the aerial part of mycorrhizal (M) and non-mycorrhizal (NM) seedlings in terms of the dilution rate of polluted soil.

Spores of the genus Scleroderma were chosen as an inoculum because of their effectiveness in stimulating the development of Pinus halepensis. In fact, it has been shown that the length and dry mass of Eucalyptus

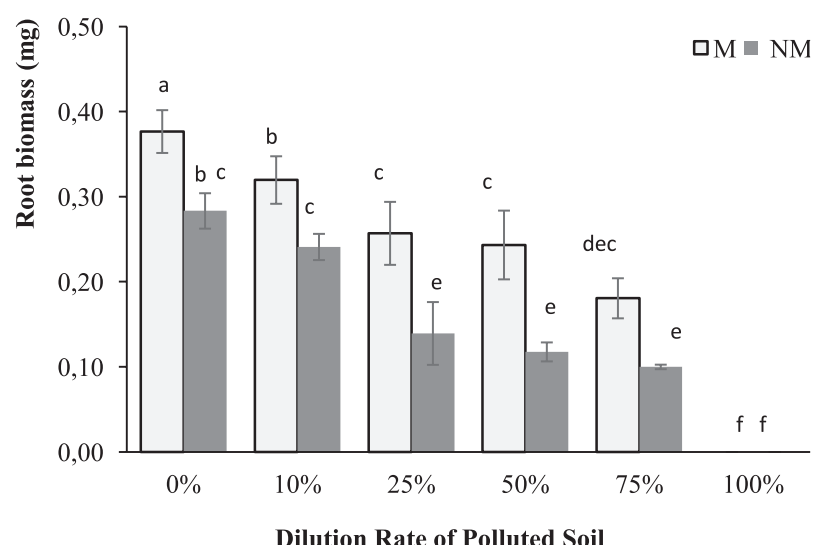

Fig. 5.The biomass of root parts of mycorrhizal (M) and nonmycorrhizal (NM) seedlings in terms of the dilution rate of the polluted soil.

and pine seedlings can be increased by $105 \%$ [53]. The survival rates of Shorea pinanga seedlings increased 3.5 times, with ectomycorrhizal inoculation with Pisolutus arhizus and Scleroderma sp. [54].

The Fig. 6 is a photographic illustration of the evolution of the morphological aspect of Pinus halepensis seedlings in terms of the dilution rate of the polluted soil of the Kettara mine diluted with sand, and shows that there was a concordance with the results obtained above.

\section{Diversity of Morphotypes of Ectomycorrhizal Apexes}

Macroscopic analysis of the roots of Pinus halepensis seedlings under a stereo-microscope allowed identifying four morphotypes of ectomycorrhizal apexes (Fig. 7). Morphotypes can be found in various forms on the same host plant [22], dichotomous with a smooth surface of light brown color, coralloid with a smooth surface of dark brown color, irregularly pinnate with a flat surface of light brown color, dichotomous with light yellowish and black brown light apex [55] the size of apexes differs from $2 \mathrm{~mm}$ to $6 \mathrm{~mm}$. In addition, microscopic observation of the apexes had revealed the fungal mantle characteristic of ectomycorrhizae and the Hartig network. Thirty-seven ectomycorrhizal types were morphologically distinguished based mainly on the color of ectomycorrhizae and the characteristics of fungal mantles [56]. For instance [57] had classified the ectomycorrhizae by morphological and anatomical tools (colour, shape, texture, and thickness of the mantle, presence and organization of emanating hyphae, rhizomorphs).

\section{Mycorrhization Rate}

In this experiment the mycorrhization rates of $(50 \%$ to $78.2 \%$ ) were respectively recorded at $75 \%$ and $0 \%$ dilution (Fig. 9). The mycorrhization rate decreased 


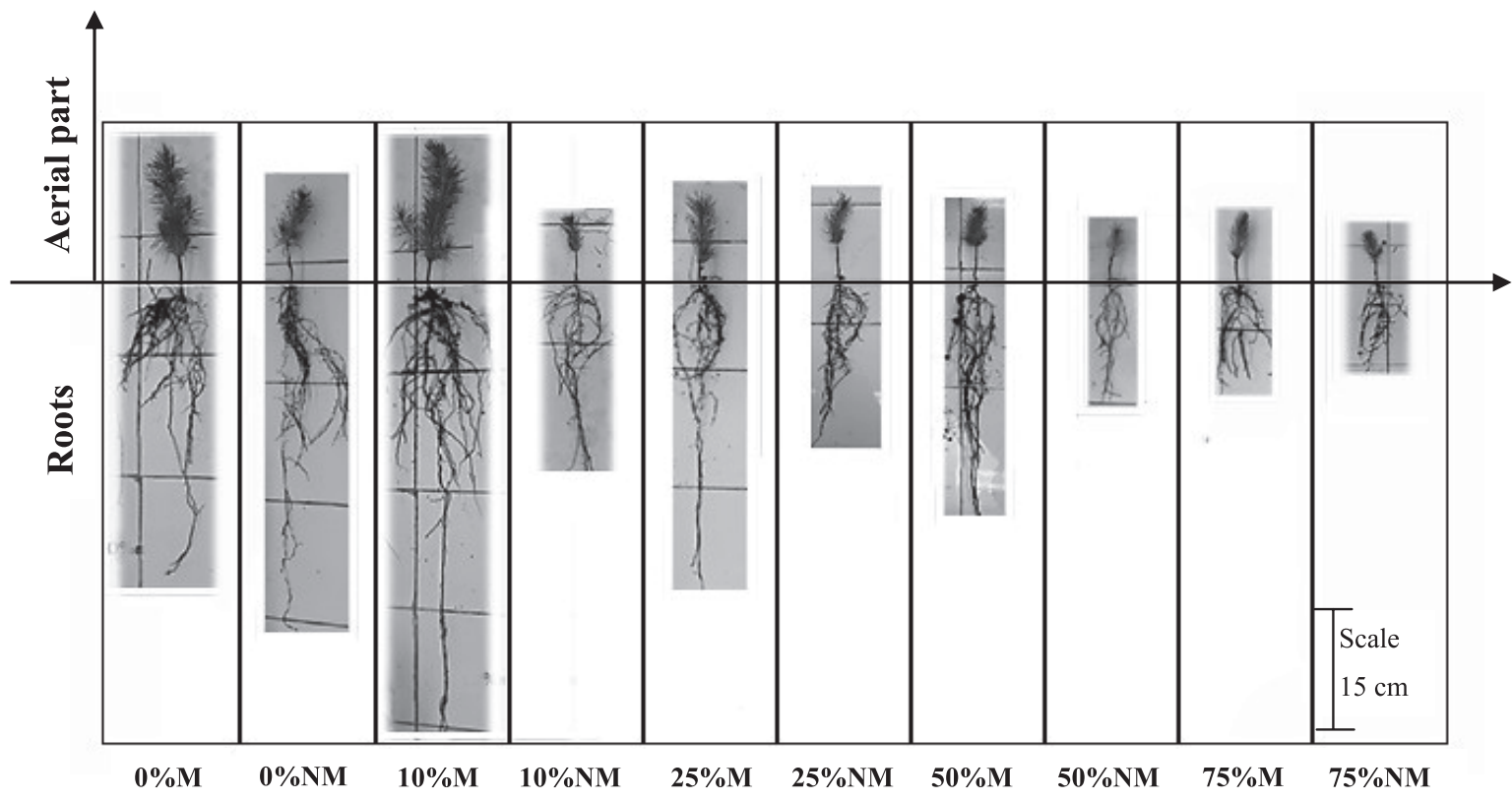

Dilution rate of the Polluted soil

Fig. 6. Illustration representing the different seedlings in terms of the dilution of the polluted soil.

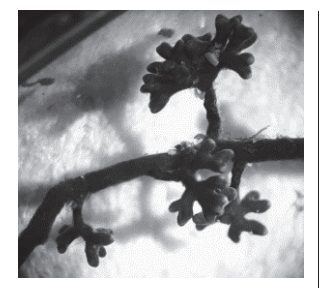

Corralloid

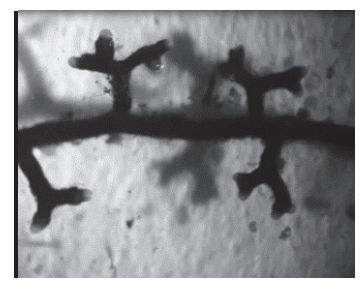

Dichotomous

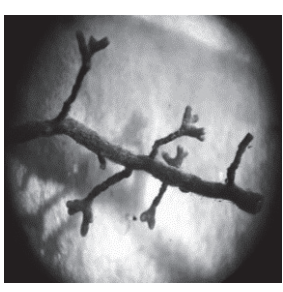

Dichotomous

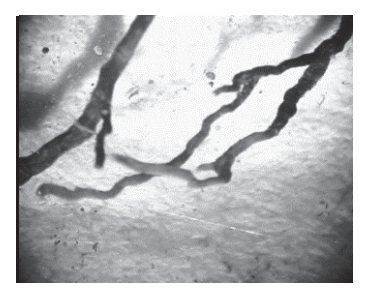

Irregularly pinnate

Dilution rate of Polluted Soil

Fig. 7. Examples of morphotypes of ectomycorrhizal apexes in Pinus halepensis.

with the increase of the dilution rate of the polluted soil at the Kettara mine site. This result can be attributed to the high level of heavy metals. The results above

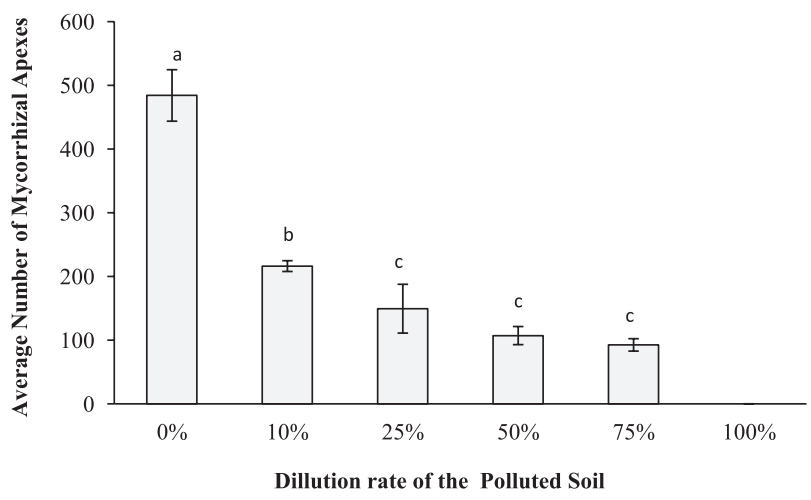

Fig. 8. The total number of mycorrhizal apexes in terms of the dilution rate of the polluted soil. had shown a positive correlation between the length of the main root, the biomass of the roots and the number of mycorrhized apexes with the mycorrhization rate

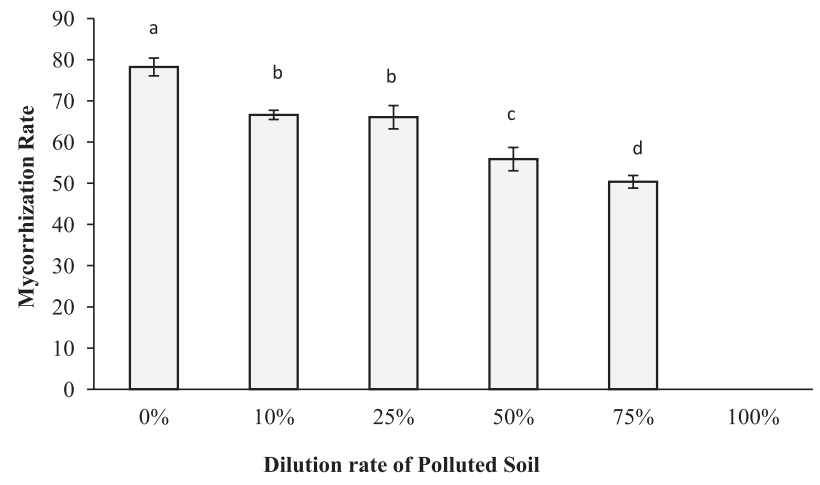

Fig. 9. Mycorrhization rate in Pinus halepensis seedlings in terms of the dilution rate of the polluted soil. 


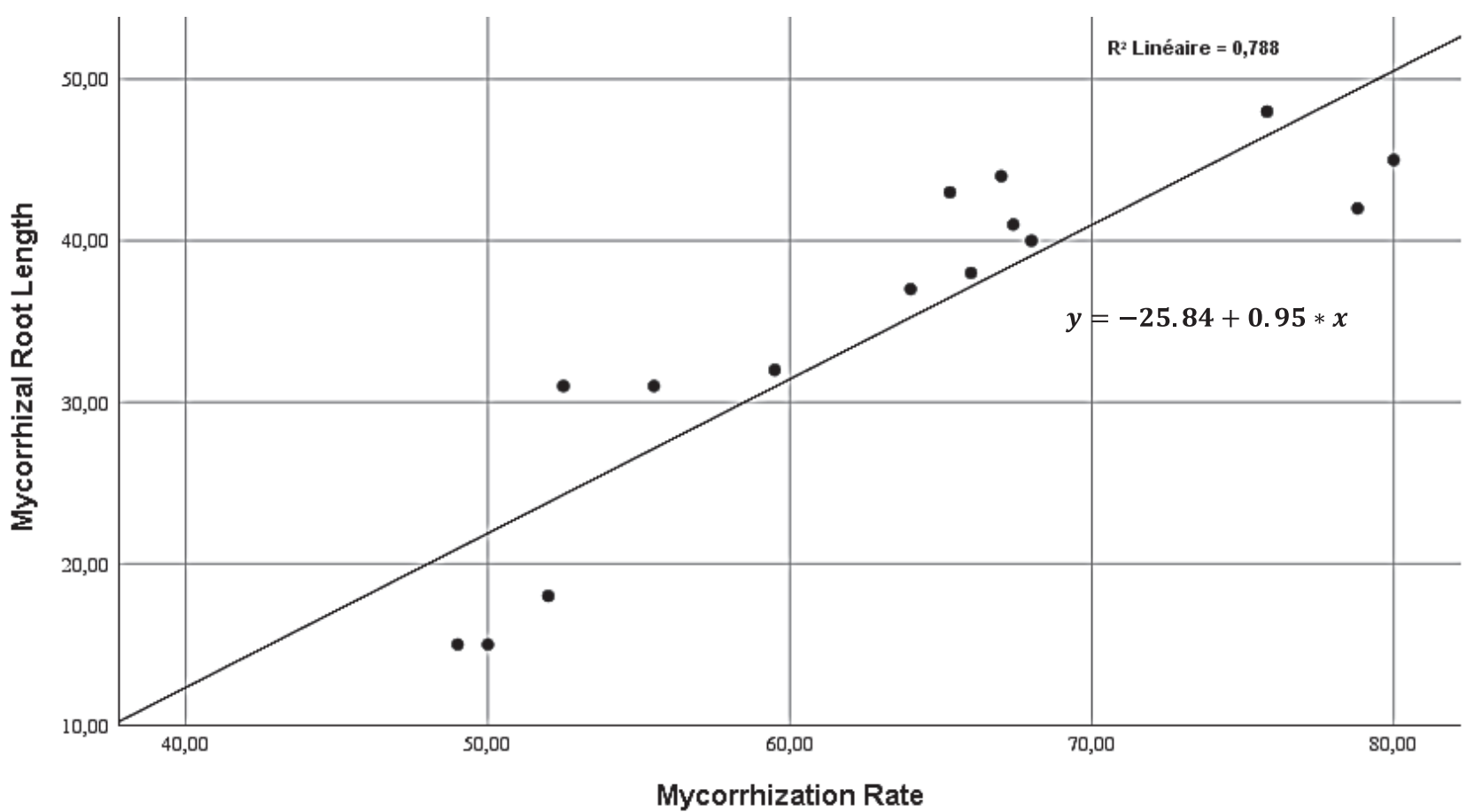

Fig. 10. The Linear correlation between the mycorrhizal root length and the mycorrhizal colonization of Pinus halepensis roots.

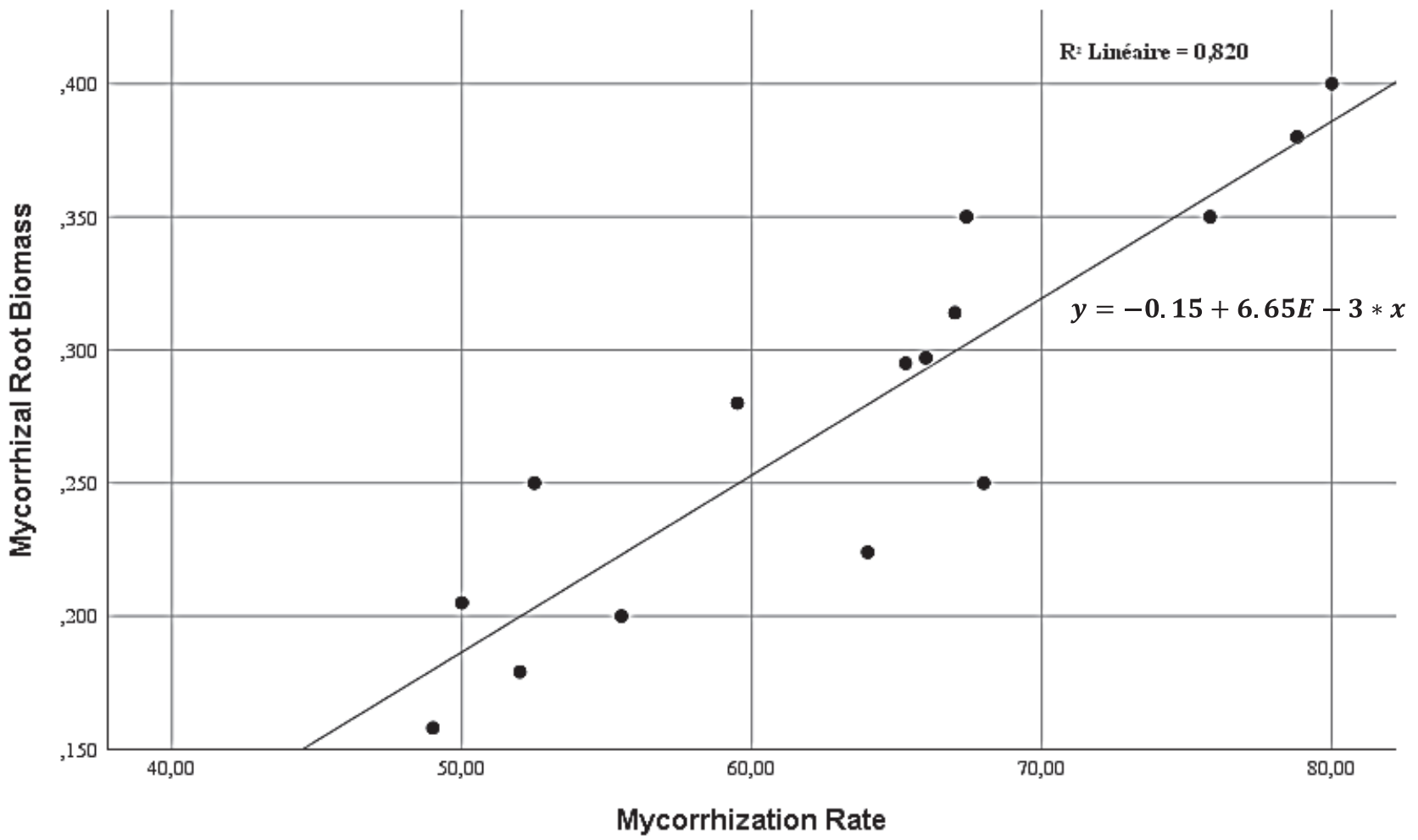

Fig. 11. The Linear correlation between mycorrhizal root biomass and the mycorrhizal colonization of Pinus halepensis roots.

(Figs 10, 11, 12). Similar results have been reported in other studies, [51] highlighted that the mycorrhization rate was gradually decreased with the increase of $\mathrm{Cu}$ or $\mathrm{Cd}$ concentrations in his experiment with the same mycorrhizal Pinus thunbergii seedlings.

\section{Conclusion}

The essential and relevant character of the phytoremediating plants was the survival and the growth at different levels of heavy metal concentration. Our results had clearly shown that Pinus halepensis 


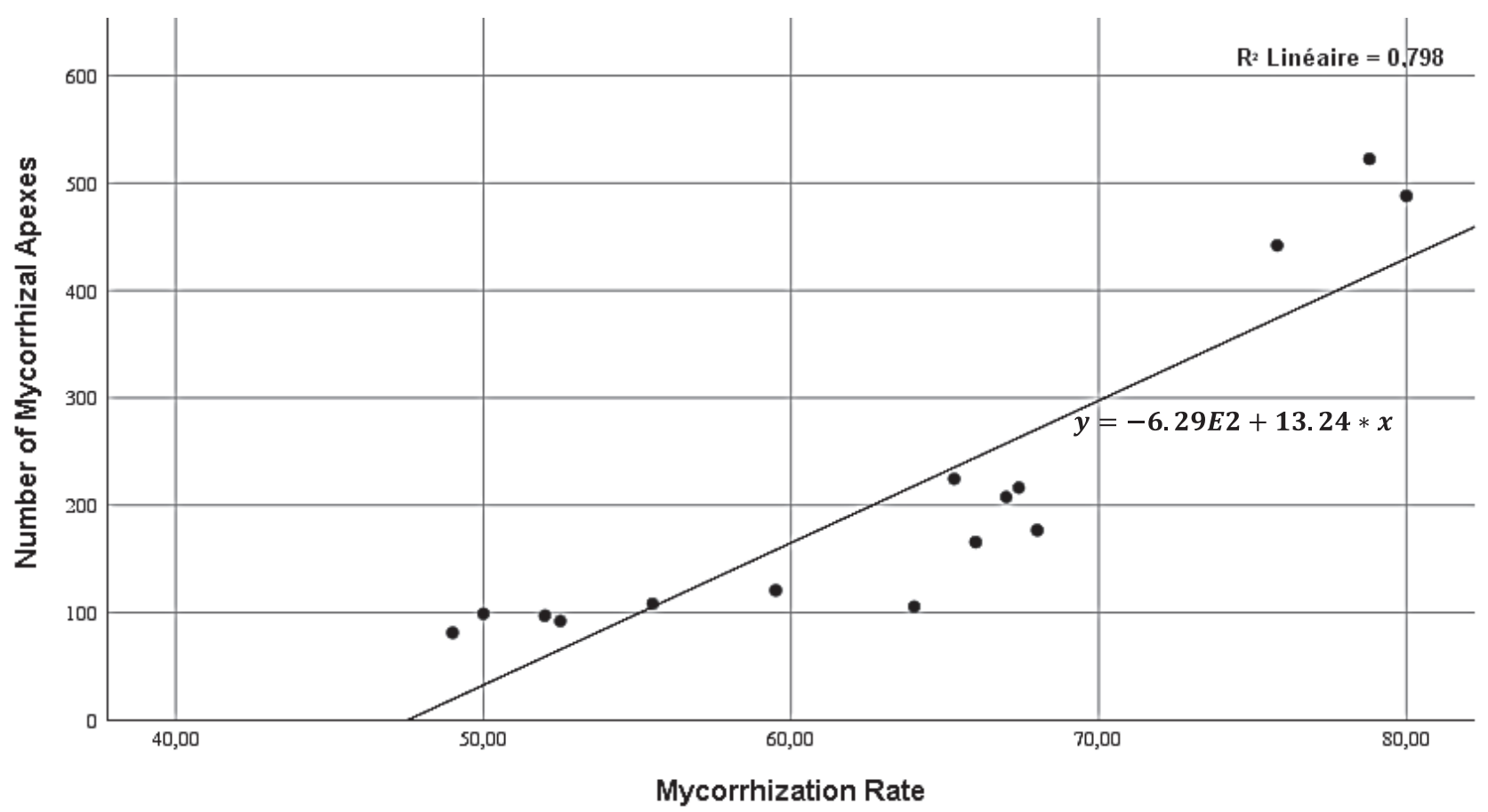

Fig. 12. The Linear correlation between the number of mycorrhizal apexes and the mycorrhizal colonization of Pinus halepensis roots.

could support a high proportion (75\%) of soil heavy metals recorded in the Kettara mine site. Furthermore, the biomass of the Pinus halepensis was increased with inoculation with the fungus belonging to Scleroderma. Then we can deduce that the ectomycorrhizal fungus helped the plant significantly to combat metallic stress. The survival represents a basis to reinforce the idea of considering Pinus halepensis inoculated with the ectomycorrhizal fungus as a phytoremediation potential to growth on contaminated soil. Our future investigation will focus on the determination of heavy metals contents in the aerial and root parts of the seedlings. The efficiency of the targeted plant under this high level of heavy metals could help to understand the strategies adopted by Pinus halepensis to survive in these highly polluted environments in the presence and absence of a mycorrhizal fungus.

\section{Conflict of Interest}

The authors declare no conflict of interest.

\section{References}

1. AMIR S. Contribution à la valorisation de boues de stations d'épuration par compostage: devenir des micropolluants métalliques et organiques et bilan humique du compost. Thèse de Doctorat, Ecole Nationale Supérieure Agronomie, Institut National Polytechnique (ENSAT-INP), Toulouse, France, 2005.

2. REYES A., THIOMBANE M., PANICO A., DANIELE L., LIMA A., DI BONITO M., DE VIVO B. Source patterns of potentially toxic elements (PTEs ) and mining activity contamination level in soils of Taltal city (northern Chile). Environmental Geochemistry and Health, 5, 22, 2019.

3. HAKKOU R., BENZAAZOUA M., BUSSIÈRE B. Acid Mine Drainage at the Abandoned Kettara Mine (Morocco): 1. Environmental Characterization. Mine Water and the Environment, 27 (3), 145, 2008.

4. LGHOUL M., KCHIKACH A., HAKKOU R., ZOUHRI L., GUERIN R., BENDJOUDI, H., HANICH L. Etude géophysique et hydrogéologique du site minier abandonné de Kettara (région de Marrakech, Maroc): contribution au projet de réhabilitation. Hydrological Sciences Journal, 57 (2), 370, 2012.

5. KHALIL A., HANICH L., BANNARI A., ZOUHRI L., POURRET O., HAKKOU R. Assessment of soil contamination around an abandoned mine in a semiarid environment using geochemistry and geostatistics: Pre-work of geochemical process modeling with numerical models. Journal of Geochemical Exploration, 125, 117. Retrieved from https://doi.org/10.1016/j.gexplo.2012.11.018 2013.

6. MIDHAT L., OUAZZANI N., ESSHAIMI M., OUHAMMOU A., MANDI L. Assessment of Heavy Metals Accumulation by Spontaneous Vegetation: Screening for New Accumulator Plant Species Grown in Kettara Mine-Marrakech, Southern Morocco. International Journal of Phytoremediation, 19 (2), 191, 2017.

7. Royaume du Maroc. dahir $\mathrm{n}^{\circ}$ 1-15-76 du 14 ramadan 1436 (1 juillet 2015)portant promulgation de la loi $\mathrm{n}^{\circ} 33-13$ relative aux mines. bulletin officiel, $\mathbf{6 3 8 4}, 3275,2015$.

8. BABI K., ASSELIN H., BENZAAZOUA M. Stakeholders' perceptions of sustainable mining in Morocco: A case study of the abandoned Kettara mine. The Extractive Industries and Society, 3 (1), 185, 2016.

9. GRZEGÓRSKA A., RYBARCZYK P., ROGALA A., ZABROCKI D. Phytoremediation - From Environment 
Cleaning to Energy Generation - Current Status and Future Perspectives. energies, 13, 43, 2020.

10. AMIR H., JOURAND P., CAVALOC Y., DUCOUSSO M. Role of Mycorrhizal Fungi in the Alleviation of Heavy Metal Toxicity in Plants. In Z.M. Solaiman et al, eds.), Mycorrhizal Fungi: Use in Sustainable Agriculture and Land Restoration, Soil Biology 41, 241, 2014.

11. ALI H., KHAN E., SAJAD M.A. Phytoremediation of heavy metals - Concepts and applications. Chemosphere, 91 (7), 869, 2013.

12. LANGER I., SANTNER J., KRPATA D., J.FITZ W., W. WENZEL W., F. SCHWEIGER P. Ectomycorrhizal impact on $\mathrm{Zn}$ accumulation of Populus tremula $\mathrm{L}$. grown in metalliferous soil with increasing levels of $\mathrm{Zn}$ concentration. plant soil, 355, 283, 2012.

13. YU P., SUN Y., HUANG Z., ZHU F., SUN Y., JIANG L. The effects of ectomycorrhizal fungi on heavy metals' transport in Pinus massoniana and bacteria community in rhizosphere soil in mine tailing area. Journal of Hazardous Materials, 381 (April 2019), 121203, 2020.

14. ARANBARRI J., ALCOLEA M., BADAL E., VILA S., ALLUÉ E., IRIARTE-CHIAPUSSO M.J., GONZÁLEZSAMPÉRIZ P. Holocene history of Aleppo pine (Pinus halepensis Mill.) woodlands in the Ebro Basin (NE Spain): Climate-biased or human-induced? Review of Palaeobotany and Palynology, 279, 104240, 2020.

15. PEREIRA C., CASTANDER-OLARIETA A., MONTALBÁN I.A., PĚNČÍK A., PETŘÍK I., PAVLOVIĆ I., MONCALEÁN P. Embryonal Masses Induced at High Temperatures in Aleppo Pine: Cytokinin Profile and Cytological Characterization. Forests, 11 (8), 807, 2020.

16. QUÉZEL P., BARBERO M. Le pin d' Alep et les espèces voisines: répartition et caractères écologiques generaux, sa dynamique récente en France méditerranéenne. Forêt méditerranéenne, 13, 158, 1992.

17. NAHAL I. Le pin d'Alep (Pinus halepensis Mill). Etude taxonomique, phytogéographique, écologique et sylvicole. In Annales de l'Ecole Nationale des Eaux Forêts 19, 208, 1962.

18. BENABID A. Flore et écosystèmes du Maroc Évaluation et préservation de la biodiversité. ibis press, 2000.

19. TOUSSAINT A., BUENO G., DAVISON J., MOORA M., TEDERSOO L., ZOBEL M., PÄRTEL M. Asymmetric patterns of global diversity among plants and mycorrhizal fungi. Journal of Vegetation Science, 31 (2), 355, 2020.

20. SANON K.B., DIANDA M., GUISSOU T., BA A.M. Description Des Champignons Ectomycorhiziens Du Genre Scleroderma De Quelques Formations Forestieres Du Burkina Faso. Cameroon Journal of Experimental Biology, 05 (2), 69, 2009.

21. GUISSOU T., BÂ A.M., PLENCHETTE C., GUINKO S., DUPONNOIS R. Effets des mycorhizes à arbuscules sur la tolérance à un stress hydrique de quatre arbres fruitiers: Balanites aegyptiaca (L) Del., Parkiabiglobosa (Jacq.) Benth., Tamarindus indica L. et zizyphus mauritiana Lam. sécheresse, 12 (2), 121, 2001.

22. BÂ A., DUPONNOIS R., DIABATÉ M., DREYFUS B. Les champignons ectomycorhiziens des arbres forestiers en Afrique de l'Ouest: Méthodes d'étude, diversité, écologie, utilisation en foresterie et comestibilité. In IRD Editions (IRD., p. 252), 2011.

23. LIU B., WANG S., WANG J., ZHANG X., SHEN Z., SHI L., CHEN Y. The great potential for phytoremediation of abandoned tailings pond using ectomycorrhizal Pinus sylvestris. Science of the Total Environment, 719, 137475, 2020.
24. KHALIL A., HANICH L., HAKKOU R., LEPAGE M. GIS-based environmental database for assessing the mine pollution: A case study of an abandoned mine site in Morocco. Journal of Geochemical Exploration, 144 (C), 468, 2014

25. ESSHAIMI M., OUAZZANI N., AVILA M., PEREZ G., VALIENTE M., MANDI L. Heavy Metal Contamination of Soils and Water Resources Kettara Abandoned Mine. American Journal of Environmental Sciences, 3, 253, 2012.

26. MIDHAT L., OUAZZANI N., HEJJAJ A., BAYO J., MANDI L. Phytostabilization of polymetallic contaminated soil using Medicago Sativa L. in combination with powdered marble: Sustainable rehabilitation. International Journal of Phytoremediation, 20 (8), 764, 2018.

27. MIDHAT L., OUAZZANI N., HEJJAJ A., OUHAMMOU A., MANDI L. Accumulation of heavy metals in metallophytes from three mining sites (Southern Centre Morocco) and evaluation of their phytoremediation potential. Ecotoxicology and Environmental Safety, 169 (2019), 150, 2019

28. AUBERT G. Methods of Soil Analysis. In G.R.D.P, Marseille 191, 1978.

29. BREMNER J.M. Nitrogen-total. In:Sparks DL (ed). Methods of soil analysis, Part 3, chemical methods-SSSA Book Series no. 5. In Soil Science Society of America 1085, 1996v

30. BENALI, EL GASMI le haut-altas de marrakech: l'homme et la dégradation de la forêt (production de charbon), 1997.

31. NOUNSI A., OUTCOUMIT A., SELMAOUI K., TOUHAMI A.O., BENKIRANE R., DOUIRA A. Inventaire des champignons ectomycorhiziens du Maroc. Journal of Applied Biosciences, 79, 6826, 2014.

32. PRANCE M., FECHNER N. Collecting and preserving fungi specimens, a manual version 2.1. Department of Science, Information Technology and Innovation, Brisbane. Retrieved from https://www.qld.gov.au/_data/ assets/pdf_file/0032/67478/fungi-coll-manual.pdf 2017.

33. NEDJIMI B., DIFI M., HADDIOUI A. Effets des différents prétraitements sur la germination des semences de pin d'Alep (Pinus halepensis Mill.). Revue des BioRessources, 4 (2), 40, 2014.

34. BILGO A., SANGARE S.K., THIOULOUSE J., PRIN Y., HIEN V., GALIANA A., DUPONNOIS R. Response of native soil microbial functions to the controlled mycorrhization of an exotic tree legume, Acacia holosericea in a Sahelian ecosystem. Mycorrhiza, 22 (3), 175,2012

35. BOUDA S., HADDIOUI A. Effet du stress salin sur la germination de quelques espèces du genre Atriplex. Nature Technologie, 5, 72, 2011.

36. GABA-CHAHBOUB H., LAMHAMEDI M.S., ABROUS-BELBACHIR O. Effet de 1 ' inoculation ectomycorhizienne en pépinière sur la croissance et la nutrition des plants du cèdre de 1' Atlas en Algérie. Bois et Forêt des Tropiques, 330 (4), 57, 2016.

37. GAGNON J., LAMHAMEDI M.S. L'inoculation des plants résineux en récipients par des spores de champignons ectomycorhiziens à l'automne pourrait-elle contribuer à réduire les problèmes d'insuffisance racinaire dans les pépinières forestières du Québec? Carrefour Forêt Innovations, 27, 2011.

38. REPAC I. Ectomycorrhizal Inoculum and Inoculation Techniques. In: Rai R., Varma A. (eds). Diversity and 
biotechnology of ectomycorrhizae. Soil biology series. Springer, Berlin, 43, 2011.

39. YAN H., KOU L., WANG H., FU X., DAI X., LI S. Contrasting root foraging strategies of two subtropical coniferous forests under an increased diversity of understory species. Plant and Soil, 436 (1-2), 427, 2019.

40. PACÉ M., PARÉ D., FENTON N.J., BERGERON Y. Effects of lichen, Sphagnum spp. and feather moss leachates on jack pine and black spruce seedling growth. Plant and Soil, 452 (1-2), 441, 2020.

41. Council Directive of the European Communities (86/278/ EEC). on the protection of the environment, and in particular of the soil, when sewage sludge is used in agriculture (86/278/EEC). Official Journal of the European Communities, L181/6, 6, 1986

42. XU Z., ZHANG T., WANG S., WANG Z. Soil pH and $\mathrm{C} / \mathrm{N}$ ratio determines spatial variations in soil microbial communities and enzymatic activities of the agricultural ecosystems in Northeast China: Jilin Province case. Applied Soil Ecology, 155 (5268), 103629, 2020.

43. REMON E., BOUCHARDON J., CORNIER B., GUY B., LECLERC J., FAURE O. Soil characteristics, heavy metal availability and vegetation recovery at a former metallurgical landfill: Implications in risk assessment and site restoration. Environmental Pollution, 137 (2005), 316, 2005.

44. LV B., ZHANG D., CUI Y., YIN F. Effects of C/N ratio and earthworms on greenhouse gas emissions during vermicomposting of sewage sludge. Bioresource Technology, 268, 408, 2018.

45. KHUONG N.Q., KANTACHOTE D., NOOKONGBUT P., ONTHONG J., THANH XUAN L.N., SUKHOOM A. Mechanisms of acid-resistant Rhodopseudomonas palustris strains to ameliorate acidic stress and promote plant growth. Biocatalysis and Agricultural Biotechnology, 24 (February), 101520, 2020.

46. FENG Y., GROGAN P., CAPORASO J.G., ZHANG H., LIN X., KNIGHT R., CHU H. Soil Biology Biochemistry $\mathrm{pH}$ is a good predictor of the distribution of anoxygenic purple phototrophic bacteria in Arctic soils. Soil Biology and Biochemistry, 74, 193, 2014.

47. RINCON A., PARLADÉ J., PERA J. Influence of the fertilisation method in controlled ectomycorrhizal inoculation of two Mediterranean pines. Annals of Forest Science, 64 (2007), 577, 2007.

48. ZONG K., HUANG J., NARA K., CHEN Y., SHEN Z., LIAN C. Inoculation of ectomycorrhizal fungi contributes to the survival of tree seedlings in a copper mine tailing. Journal of Forest Research, 20 (6), 493, 2015.
49. MORTE A., DÍAZ G., RODRÍGUEZ P., ALARCÓN J.J., SÁNCHEZ-BLANCO M.J. Growth and Water Relations in Mycorrhizal and Nonmycorrhizal Pinus Halepensis Plants in Response to Drought. Biologia Plantarum, 44 (2), 263, 2001.

50. RADI M., HAMDALI H., ABDELILAH M., LAHCEN O., HAFIDI M. Le potentiel mycorhizogène des sols urbains en zones semi-arides et la tolérance du Palmier dattier (Phoenix dactylifera L.) au déficit hydrique. Journal of Materials and Environmental Science, 5 (6), 1957, 2014.

51. CHATURVEDI R., FAVAS P., PRATAS J., VARUN M., PAUL M.S. Assessment of edibility and effect of arbuscular mycorrhizal fungi on Solanum melongena L. grown under heavy metal (loid) contaminated soil. Ecotoxicology and Environmental Safety, 148 (2018), 318, 2018.

52. TANG Y., SHI L., ZHONG K., SHEN Z., CHEN Y. Ectomycorrhizal Fungi May Not Act as A Barrier Inhibiting Host Plant Absorption of Heavy Metals. Chemosphere, 215, 115, 2019.

53. CHEN Y.L., KANG L.H., MALAJCZUK N., DELL B. Selecting ectomycorrhizal fungi for inoculating plantations in south China: effect of Scleroderma on colonization and growth of exotic Eucalyptus globulus, E. urophylla, Pinus elliottii, and P. radiata. Mycorrhiza, 16, 251, 2006.

54. TURJAMAN M., TAMAI Y., SEGAH H., LIMIN S.H., CHA J.O.O.Y., OSAKI M., TAWARAYA K. Inoculation with the ectomycorrhizal fungi Pisolithus arhizus and Scleroderma sp . improves early growth of Shorea pinanga nursery seedlings. New Forests, 30, 67, 2005.

55. AGERER R. Anatomical Characteristics of Identified Ectomycorrhizas: An Attempt Towards a Natural Classification. In Mycorrhiza, 685, 1995.

56. MATSUDA Y., HIJII N. Ectomycorrhizal morphotypes of naturally grown Abies firma seedlings. Mycoscience, 40, 217, 1999.

57. OLCHOWIK J., SUCHOCKA M., MALEWSKI T., BACZEWSKA-DABROWSKA A., STUDNICKI M., HILSZCZANSKA D. The Ectomycorrhizal Community of Crimean Linden Trees in Warsaw, Poland. Forests, 11, 926, 2020.

58. NFISSI S., ALIKOUSS S., ZERHOUNI Y., HAKKOU R., BENZAAZOUA M., BOUZAHZAH H. Control of acid mine drainage from an abandoned mine in Morocco by using cement kiln dust and fly ash as amendments. Journal of Materials and Environmental Sciences, 8 (12), 4457, 2017. 
